\title{
Functional analyses of C13orf19/P38IP in prostate cell lines
}

\author{
DOREEN KUNZE, SUSANNE FUESSEL, AXEL MEYE, MANFRED P. WIRTH and UTA SCHMIDT ${ }^{1}$ \\ Department of Urology, Technical University Dresden, Fetscherstrasse 74, D-01307 Dresden, Germany
}

Received December 2, 2005; Accepted February 2, 2006

\begin{abstract}
Human C13orf19 was previously identified to be downregulated in prostate cancer $(\mathrm{PCa})$ but its function is unknown to date. In the present study, C13orf19 mRNA expression was inhibited by siRNA transfection. Furthermore, a possible regulation by androgens and the previously postulated interaction with p38 MAP kinase (p38MAPK) was investigated. The siRNA-mediated downregulation of the C13orf19 mRNA expression in the prostate cell lines PC-3 and BPH-1 was examined by quantitative PCR. Cellular viability, apoptosis, cell cycle distribution and clonogenic survival were investigated. In addition, the effects of C13orf19 downregulation in combination with chemotherapy on overall cell survival were studied. The inhibition of C13orf19 mRNA expression to $12 \%$ (after $12 \mathrm{~h}$ ) and $55 \%$ (after $96 \mathrm{~h}$ ) in PC-3 cells attested to a strong and persistent molecular effect provoked by the siRNA-D5 construct. However, no obvious effects on doubling time and cellular morphology were observed. Cell cycle distribution, clonogenic survival, apoptosis and cell viability showed no alterations, even after combining siRNA transfection with chemotherapy. Therefore, it can be concluded that the reduced expression of C13orf19 in PCa is not involved in the malignant transformation of the cells. A possible androgen dependence of C13orf19 mRNA expression was investigated by treating LNCaP cells with the androgen R1881 and in combination with the antiandrogen, bicalutamide. C13orf19 is expressed independently of the androgen. To analyze the putative interaction between C13orf19 and p38MAPK, PC-3 and BPH-1 cells were treated with the p38MAPK inhibitor, SB203580, and C13orf19 mRNA expression was examined. Additionally, the expression and phosphorylation status of p38MAPK after the inhibition of C13orf19 was investigated by Western blotting. No interaction between C13orf19 and p38MAPK was identified. Therefore, the gene should forthwith be named C13orf19 or FAM48A and not P38IP.
\end{abstract}

Correspondence to: Doreen Kunze, Department of Urology, Technical University Dresden, Fetscherstrasse 74, D-01307 Dresden, Germany

E-mail: doreen.kunze@uniklinikum-dresden.de

Present address: ${ }^{1}$ Department of Physiological Chemistry, University of Ulm, Albert-Einstein-Allee 11, D-89081, Ulm, Germany

Key words: chromosome 13, lipid-mediated siRNA transfection, prostate cancer

\section{Introduction}

In 2005, an estimated 232,090 new cases of prostate cancer (PCa) will be diagnosed in the U.S., and approximately 30,350 men will die of the disease (1). These numbers make PCa the most common malignancy in men and the second leading cause of cancer deaths. Among the genetic alterations identified so far, abberations of chromosome $13 \mathrm{q}$ are, together with losses of $8 \mathrm{p}$ and gains of $8 \mathrm{q}$, the most frequent chromosomal changes in PCa (2). Another study described up to $72 \%$ loss of heterozygosity ( $\mathrm{LOH}$ ) on chromosome 13q (3). These changes have led to the hypothesis that at least one prostatespecific tumor suppressor gene resides on chromosome 13q.

We have previously reported the identification of the P38IP gene, also known as C13orf19 or FAM48A, whose mRNA was downregulated in PCa (4). By means of in situ hybridization, we showed that its mRNA is expressed exclusively in the epithelia of the prostate. $\mathrm{LOH}$ in the chromosomal region of the C13orf19 gene in $47 \%$ of the patients was higher for seven C13orf19-associated markers than for the four markers of the RB1 locus (39\%) and three BRCA2-related markers $(25 \%)$ on $13 q(5)$. We were also able to validate our initial data on the PCa-associated downregulation of C13orf19 in a cohort of 61 patients; an at least 1.5-fold lower mRNA level was observed in samples from $46 \%$ of the patients (6).

The identified C13orf19 cDNA encodes a protein of 733 amino acids with a nuclear localization signal, glutamine clusters, and an $\alpha$-helix-rich $\mathrm{N}$-terminal part. A homology search in BLAST mode revealed some similarity with proteins known to be involved in transcription regulation, such as the CREB binding protein and its homologues, a zinc finger homeodomain protein, the TATA-box binding protein and the androgen receptor. The high scores for the similarity between C13orf19 and the transcription factors are mainly due to glutamine clusters in the C-terminal part of C13orf19 (4).

The first database entry described C13orf19 as P38IP (acc. no. AF093250), a protein that interacts with the p38 map kinase (MAPK). This description was given by J. Han (Scripps Research Institute, La Jolla, CA, USA) because of the identification of P38IP in a yeast two-hybrid screen with p38MAPK (personal communication).

The aim of this study was to show whether a C13orf19 knockdown by means of siRNA will have an effect on PCa cell growth, apoptosis or cell cycle distribution. Also, a possible regulation by androgens was investigated. Furthermore, the described interaction with p38MAPK was pharmacologically verified, and additional interaction partners were identified in an independent yeast two-hybrid screen. 
Table I. Inhibition of C13orfl9 mRNA expression after transfection with $250 \mathrm{nM}$ siRNA-D5 in the PC-3 cell line.

\begin{tabular}{cc}
\hline $\begin{array}{c}\text { Time after } \\
\text { transfection }\end{array}$ & $\begin{array}{c}\text { Inhibition of C13orf19 mRNA } \\
\text { expression in comparison to ns-siRNA }\end{array}$ \\
\hline $12 \mathrm{~h}$ & $12 \%$ \\
$24 \mathrm{~h}$ & $16 \%$ \\
$48 \mathrm{~h}$ & $23 \%$ \\
$72 \mathrm{~h}$ & $31 \%$ \\
$96 \mathrm{~h}$ & $55 \%$ \\
\hline
\end{tabular}

The results are indicated relative to the reference gene, PBGD, and normalized to the non-silencing-siRNA control.

\section{Materials and methods}

Cell culture, siRNAs and transfection. The human prostate (BPH-1) and prostate cancer (PC-3, LNCaP) cell lines were cultured under standard conditions $\left(37^{\circ} \mathrm{C}\right.$, humidified atmosphere containing 5\% $\mathrm{CO}_{2}$ ) without antibiotics in DMEM ( $4.5 \mathrm{~g} / \mathrm{l}$ glucose) containing $10 \%$ fetal calf serum (FCS), $1 \%$ MEM and 1\% HEPES (all from Invitrogen, Karlsruhe, Germany). SiRNA-D5 (sense, AGAUGAUUAUGUAUU UGAAdTdT; antisense, UUCAAAUACAUAAUCAUC UdTdT) targeting the C13orf19 mRNA (NM_017569) as well as the non-silencing (ns-) siRNA-control (sense, UUC UUCGAACGUGUCACGUdTdT; antisense, ACGUGACAC GUUCGGAGAAdTdT) were synthesized by Qiagen (Hilden, Germany). Ns-siRNA treatment was used for normalization. After seeding in 96- or 6-well plates and adherence for 24-72 h, the cells were transfected with siRNA (125 or $250 \mathrm{nM}$ ) using DOTAP liposomal transfection reagent (ratio 1:4, w/w, diluted in Opti-MEM) according to the manufacturer's instructions (Roche, Mannheim, Germany). Following transfection for $4 \mathrm{~h}$ at $37^{\circ} \mathrm{C}$, the cells were washed with PBS and incubated in serum-containing medium for 24-72 $\mathrm{h}$. The cells were harvested by trypsin treatment $(0.05 \%$ trypsin/ $0.02 \% \mathrm{EDTA})$ for $5 \mathrm{~min}$ at $37^{\circ} \mathrm{C}$.

Chemotherapeutic agents and treatment. Docetaxel and etoposide were diluted at different concentrations in culture medium. The cells were incubated $24 \mathrm{~h}$ after siRNA transfection with the chemotherapeutic agents (CT) for $24 \mathrm{~h}$ followed by PBS washing and further cultivation. Detached and adherent cells were pooled and analyzed together. The ns-siRNA+CT combination was used as a control to evaluate the siRNA-mediated effect of this combination treatment.

Treatment with the p38MAPK inhibitor, SB203580. After seeding in 6-well plates and cultivation for $24-72 \mathrm{~h}$, the cells were washed with PBS and incubated in medium without FCS for 24-72 h. Stock solution of the inhibitor, SB203580, in DMSO (1 mg/ml; Merck, Darmstadt, Germany) was diluted 1:10 in sterile water and added to the cells for $1 \mathrm{~h}$ with final concentrations of between 0.5 and $8.0 \mu \mathrm{M}$.

Androgen stimulation and antiandrogen treatment of hormone-sensitive LNCaP cells. Cells $\left(1.2 \times 10^{6}\right)$ were plated

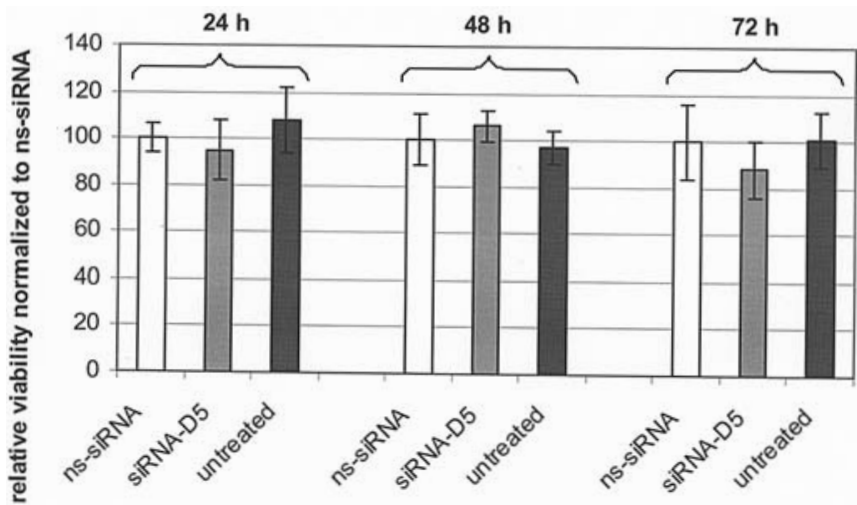

Figure 1. Relative cell viability of PC-3 cells $48 \mathrm{~h}$ after transfection with $125 \mathrm{nM}$ siRNA-D5 normalized to cells treated with ns-siRNA (100\%).

in $75-\mathrm{cm}^{2}$ flasks and incubated overnight in RPMI medium without phenol red completed with non-essential amino acids, $10 \mathrm{mM}$ HEPES and 10\% charcoal-stripped FCS (Biochrom, Berlin, Germany) in the absence of androgen. Cell culture was continued for an additional $48 \mathrm{~h}$ in this medium in the presence of 1 or $10 \mathrm{nM}$ of the synthetic androgen, methyltrienolone (R1881; Perking-Elmer Life Sciences, Rodgau, Germany). Cells were harvested at different time points after hormone addition (Fig. 4). For antiandrogen treatment, cells were cultured and stimulated with 1 or $10 \mathrm{mM} \mathrm{R} 1881$ as described above with the addition of bicalutamide (AstraZeneca, Macclesfield, UK) at a final concentration of $10 \mu \mathrm{M}$ using a $10 \mathrm{mM}$ stock solution prepared in ethanol.

Cell viability and clonogenic survival. Cellular viability was examined in quadruplicate 24-72 h after transfection using WST-1 cell proliferation reagent (Roche). To examine clonogenic survival, 100-200 cells were seeded in triplicate in 6-well plates and cultivated for 10-12 days. Before colony counting, the cells were fixed with $4 \%$ formaldehyde and stained with Giemsa (Merck).

Apoptosis detection and cell cycle analysis. Apoptosis was assessed by annexin $\mathrm{V}$ and propidium iodide (PI) staining (Annexin V-FITC Apoptosis Detection kit I; BD Biosciences, Heidelberg, Germany) using flow cytofluorometry 24, 48 and $72 \mathrm{~h}$ after transfection (FACScan, BD Biosciences). The annexin V-FITC/PI plots of $2 \times 10^{4}$ cells were examined by quadrant analysis using WinMDI2.8 software (http://facs. scripps.edu/software.html). PI counterstaining allows the discrimination of early (annexin V-positive, PI-negative) and late apoptotic cells (double positive). The CycleTest Plus DNA reagent kit (BD Biosciences) was used for cell cycle analysis according to the manufacturer's instructions.

Total RNA isolation and quantitative PCR. Cellular RNA was isolated according to the manufacturer's instructions at defined times after transfection (Invisorb Spin Cell RNA Mini kit; Invitek, Berlin, Germany). The transcript amounts of C13orf19 (primers, gaccgatgctgagagggtag and accgaagac tgaactgacacg; probes, gagccactggagctgtgtgacatc-fluorescein and LightCycler Red640-tgaccggacatttggcttcattctg-PH), PBGD (porphobilinogen deaminase), PSA (prostate-specific 


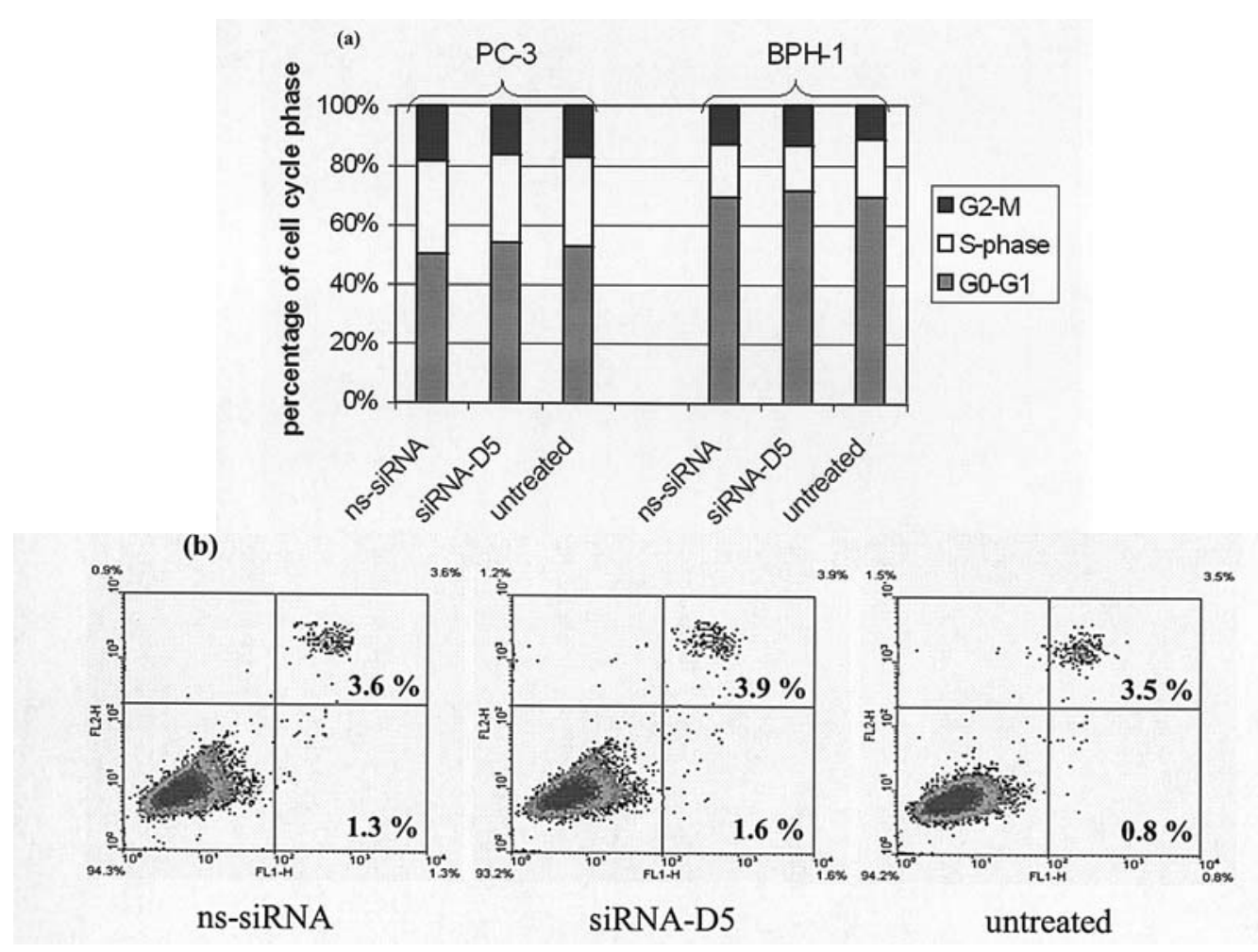

Figure 2. Cell cycle distribution (a) and rate of apoptosis (b) of PC-3 cells $48 \mathrm{~h}$ after transfection with $125 \mathrm{nM}$ siRNA-D5. For each apoptosis assay, $1.5 \mathrm{x} 10^{4}$ cells were used. The proportions $(\%)$ of early (lower right: annexin V-positive, PI-negative) and late apoptotic cells (upper right: annexin V-positive, PIpositive) are shown

antigen) and TBP (TATA box binding protein) were determined by quantitative real-time PCR (qPCR) using the LightCycler FastStart DNA Master hybridization probes kit and LightCycler instrument (both from Roche). In-house assays were applied for the PBGD, PSA and TBP genes.

Immunoblotting. Cells $\left(5 \times 10^{4}\right.$ per sample) were lysed in loading buffer (20\% glycerol, $2 \%$ SDS, 125 mM Tris pH 6.8, $5 \%$ B-mercaptoethanol and bromophenol blue), incubated at $95^{\circ} \mathrm{C}$ for $5 \mathrm{~min}$ and separated on $12 \%$ SDS-polyacrylamide gels. Western blot analysis was performed according to the protocol provided for the primary phospho-p38 MAP kinase and p38 MAP kinase antibodies $(1: 1,000$; Cell Signaling Technology, Beverly, MA, USA), which recognize the phosphorylated or total p38MAPK protein $(40 \mathrm{kDa})$, respectively. $\beta$-actin, detected by a monoclonal anti- $\beta$-actin antibody (1:5,000; Sigma, St. Louis, MO, USA), served as a loading control. Secondary anti-rabbit IgG HRP-linked antibody (1:1,000; Amersham Biosciences, Freiburg, Germany) for p38MAPK, secondary anti-mouse immunoglobin HRP-linked antibody (1:1,000; Dako, Glostrup, Denmark) for ß-actin, and the enhanced chemiluminescence kit (Amersham Biosciences) were used for visualization.

\section{Results}

The effects of siRNA-D5-mediated C13orf19 mRNA inhibition in the $\mathrm{BPH}-1$ prostate cell line and the $\mathrm{PC}-3$ prostate cancer cell line were examined. Treatment with $250 \mathrm{nM}$ siRNA-D5 remarkably reduced C13orf19 mRNA expression in PC-3 cells $12 \mathrm{~h}$ after transfection to $12 \%$ compared with the non- silencing siRNA control (Table I). Even 96 h after siRNA-D5 transfection, a decrease of the transcript level to $55 \%$ was measured by qPCR. An equal C13orf19 mRNA reduction was detected in BPH-1 cells (data not shown). A similar inhibition rate of C13orf19 transcript number was determined using $125 \mathrm{nM}$ of siRNA-D5 $24 \mathrm{~h}$ after transfection (data not shown). For the subsequent analyses of potential cellular effects, all further experiments were performed at this lower concentration (125 nM).

Despite the effective and persistent reduction of C13orf19 mRNA expression, the WST-1 cell viability assay showed no significant alterations in the viability of either cell line 24, 48 and $72 \mathrm{~h}$ after siRNA-D5 transfection (Fig. 1; data for BPH-1 not shown). Also, cell cycle distribution and the rate of apoptosis showed no adjustments (Fig. 2; data for BPH-1 not shown). Since the apoptosis rate was low in the PC-3 cell line, siRNA treatment was combined with chemotherapy to increase the rate of apoptosis. However, no changes in viability, cell cycle distribution and apoptosis occurred after the combination of siRNA-D5 and etoposide or docetaxel in comparison to the controls consisting of a chemotherapeutic agent and nssiRNA (data not shown).

The dependence of C13orf19 mRNA expression on the R1881 androgen was investigated after stimulation of hormone-sensitive LNCaP cells with R1881. Neither treatment with R1881 at both concentrations (1 and $10 \mathrm{nM}$ ) nor combination with the antiandrogen, bicalutamide, changed the C13orf19 transcript expression (Fig. 3).

We also investigated the putative interaction between C13orf19 and p38MAPK. Therefore, C13orf19 mRNA expression was measured after treatment of BPH-1 and PC-3 


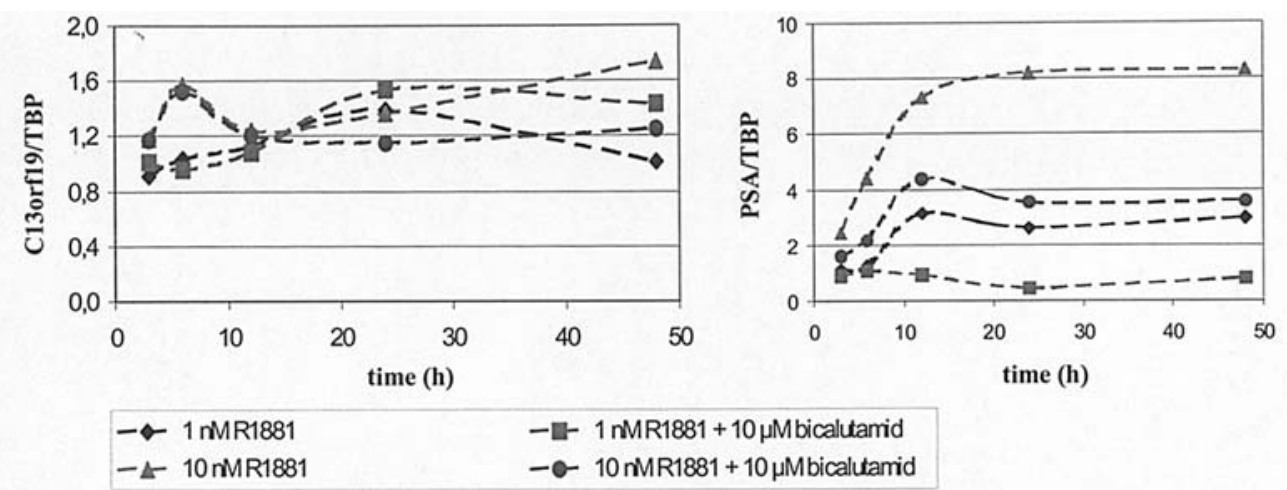

Figure 3. C13orf19 mRNA expression in LNCaP cells after treatment with the synthetic androgen, R1881, or combined with R1881 and the antiandrogen, bicalutamide. In contrast, the androgen dependence of prostate-specific antigen (PSA) mRNA expression was measured in the same experiment. Both transcript numbers were normalized to the TBP reference gene.

(a)

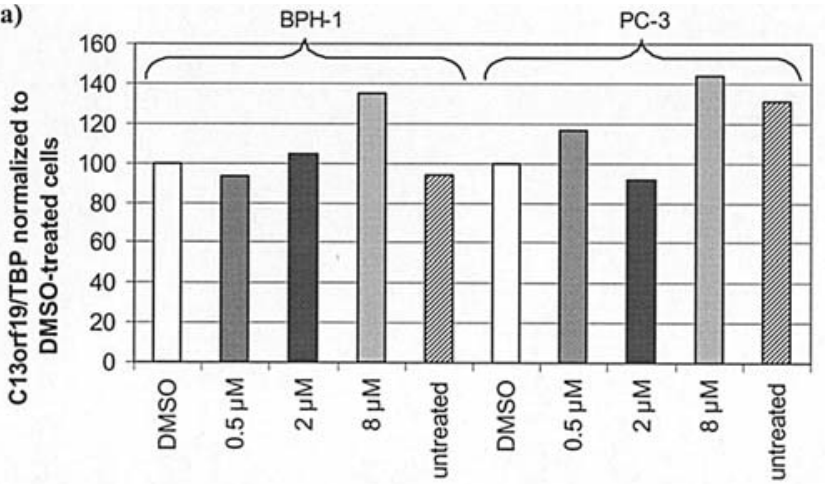

(b)

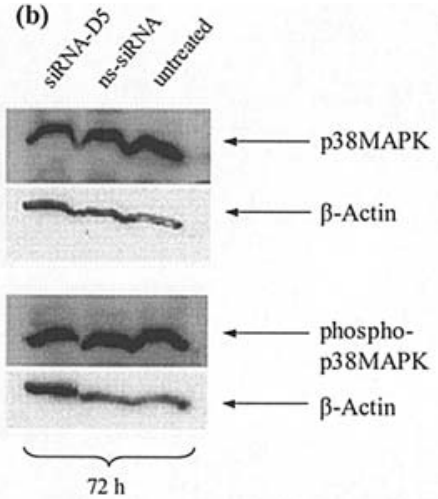

Figure 4. Examination of C13orf19 interaction with p38MAPK. (a) C13orf19 mRNA expression in BPH-1 and PC-3 cells after treatment with the p38MAPK inhibitor, SB203580, relative to the TBP reference gene normalized to DMSO-treated cells. (b) Western blot analysis of PC-3 cells $72 \mathrm{~h}$ after transfection with siRNA-D5. The antibodies recognized total (upper) or phosphorylated (lower) p38MAPK protein. B-actin served as a loading control.

cells with the p38MAPK inhibitor, SB203580 (Fig. 4a). The expression of C13orf19 did not change after p38MAPK inhibition. Furthermore, the p38MAPK expression and phosphorylation status after siRNA-D5-mediated C13orf19knockdown was examined in the PC-3 cell line by Western blotting (Fig. 4b). The treatment with siRNA-D5 did not change the expression or phosphorylation of p38MAPK.

\section{Discussion}

The C13orf19 gene and its product were thought to be involved in the malignant transformation of prostate cells because of its localization on chromosome $13 \mathrm{q}$, which is often affected by $\mathrm{LOH}$ in PCa (3), its epithelial mRNA expression and the sequence similarity of its putative protein to transcription factors (4-6). Experiments to increase the C13orf19 mRNA expression through stable transfection as GFP fusion protein in the PCa cell lines, DU145 and 22RV1, did not change cell growth (unpublished data). Another possibility to examine the function of the gene is the selective inhibition of its mRNA expression using RNA interference as performed in the present study.

Transfection of BPH-1 and PC-3 cells with siRNA-D5 significantly reduced C13orf 19 mRNA expression. Despite this strong molecular effect, no alterations in the cellular phenotype (changes in proliferation, apoptosis or cell cycle distribution) were observed in either cell type. Also, the combination of siRNA transfection with chemotherapy did not effect the growth of PC-3 cells.

By means of qPCR, a significant downregulation of C13orf19 mRNA expression in malignant prostate tissues in comparison to the non-malignant counterparts was observed in $46 \%$ of the patients (6). However, $28 \%$ of the patients showed a 1.5 -fold increase in transcript expression. Further analyses did not indicate a correlation between C13orf19 expression and the stage or other clinicopathological criteria of PCa.

The results of this study were compared with other studies that examined C13orf19 expression. On a public website (www.oncomine.org), the data of microarray studies were compared in terms of the expression of a selected gene in different tissues using the Student's t-test. Syllabi of the findings for C13orf19 from different studies are summarized in Table II. Only in one study describing a comparison of 59 patients with primary $\mathrm{PCa}$ and 20 patients with metastatic $\mathrm{PCa}$ the mean values of the two groups were significantly different $(\mathrm{p}=0.032)(14)$; C13orf19 was underexpressed in patients with metastases (Table II). No trend of C13orf19 mRNA expression in different prostate tissues was found in the other studies. Since targets are usually identified by an at least 2- 
Table II. C13orf19 mRNA expression studies (microarray analyses).

\begin{tabular}{|c|c|c|c|c|c|c|c|}
\hline $\begin{array}{l}\text { Study } \\
\text { (reference) }\end{array}$ & Matrix 1 & Matrix 2 & mv 1 & mv 2 & $\mathrm{~T}$ & p-value & $\begin{array}{l}\text { Adjusted } \\
\text { p-value }\end{array}$ \\
\hline $\begin{array}{l}\text { Welsh } \\
\text { prostate (9) }\end{array}$ & $\begin{array}{l}\text { Normal prostate, } \\
n=9\end{array}$ & $\begin{array}{l}\text { Prostate cancer, } \\
n=25\end{array}$ & -0.801 & -0.415 & -2.553 & 0.026 & $>1.000$ \\
\hline $\begin{array}{l}\text { Singh } \\
\text { prostate (10) }\end{array}$ & $\begin{array}{l}\text { Non-tumor prostate, } \\
n=50\end{array}$ & $\begin{array}{l}\text { Prostate tumor, } \\
\mathrm{n}=52\end{array}$ & -1.026 & -1.128 & 0.803 & 0.425 & $>1.000$ \\
\hline $\begin{array}{l}\text { Ramaswamy } \\
\text { multicancer } \\
\text { (11) }\end{array}$ & $\begin{array}{l}\text { Prostate, } \\
n=23\end{array}$ & $\begin{array}{l}\text { Prostate } \\
\text { adenocarcinoma, } \\
n=14\end{array}$ & -1.487 & -1.527 & 0.09 & 0.932 & $>1.000$ \\
\hline $\begin{array}{l}\text { Luo } \\
\text { prostate (12) }\end{array}$ & $\begin{array}{l}\text { Benign prostatic } \\
\text { hyperplasia, } n=9\end{array}$ & $\begin{array}{l}\text { Prostate cancer, } \\
n=16\end{array}$ & -0.13 & -0.123 & -0.035 & 0.972 & $>1.000$ \\
\hline $\begin{array}{l}\text { Luo JH } \\
\text { Prostate (13) }\end{array}$ & $\begin{array}{l}\text { Normal adjacent } \\
\text { prostate, } n=15\end{array}$ & $\begin{array}{l}\text { Prostate cancer, } \\
\mathrm{n}=15\end{array}$ & -1.785 & -2.443 & 1.636 & 0.138 & $>1.000$ \\
\hline $\begin{array}{l}\text { Dhanasekaran } \\
\text { prostate (14) }\end{array}$ & $\begin{array}{l}\text { Benign prostatic } \\
\text { hyperplasia, } n=16 ; \\
\text { normal prostate, } n=6\end{array}$ & $\begin{array}{l}\text { Primary prostate } \\
\text { cancer, } n=59\end{array}$ & 0.712 & 0.726 & -0.089 & 0.929 & $>1.000$ \\
\hline $\begin{array}{l}\text { Dhanasekaran } \\
\text { prostate (14) }\end{array}$ & $\begin{array}{l}\text { Primary prostate cancer, } \\
\mathrm{n}=59\end{array}$ & $\begin{array}{l}\text { Prostate cancer } \\
\text { metastasis, } n=20\end{array}$ & 0.726 & 0.095 & 4.257 & $1.4 \mathrm{E}-4$ & 0.032 \\
\hline $\begin{array}{l}\text { LaTulippe } \\
\text { prostate (15) }\end{array}$ & $\begin{array}{l}\text { Primary prostate } \\
\text { carcinoma, } n=23\end{array}$ & $\begin{array}{l}\text { Prostate cancer } \\
\text { metastasis, } n=9\end{array}$ & -0.393 & -0.412 & 0.128 & 0.899 & $>1.000$ \\
\hline
\end{tabular}

Matrix 1 and 2 are the two groups to be compared. $\mathrm{N}$ indicates the quantity of patients in each group. Mv 1 and 2 represent the mean values of the matrices. The adjusted p-value specifies the significance of the mv, i.e. the p-value was Bonferroni-adjusted. Bold, higher mv.

fold change in expression in the context of microarray analyses (7), the microarray analyses used in these studies are less sensitive in detecting alterations of expression than the qPCR analyses performed in our study (6). Therefore, the results can only be compared conditionally.

Therefore, the reduced expression of C13orf19 in $\mathrm{PCa}$ does not seem to play a key role in PCa formation. The previously detected decrease in expression probably represents an accompanying effect of LOH on chromosome 13q. Furthermore, the C13orf19 mRNA reduction could be associated with the progression of $\mathrm{PCa}$. It might be possible to obtain further functional information about the gene by performing microarray analyses after siRNA-induced C13orf19 mRNA inhibition.

Since PCa mainly grow hormone sensitive in the initial stage and become hormone refractory in the advanced stage, the androgen dependence of the expression of genes that could be involved in the genesis or progression of $\mathrm{PCa}$ is particularly interesting. The performed experiments with the hormone-sensitive LNCaP cell line showed, in contrast to the control measurement for the mRNA level of PSA, an androgenindependent expression of C13orf19.

In non-malignant prostate tissue, the $\mathrm{p} 38 \mathrm{MAPK}$ protein is present in the stroma as well as in epithelial and basal cells, whereas it is phosphorylated in the stroma but not in the epithelial layer (16). In the case of $\mathrm{BPH}$ or PCa, epithelial p38MAPK can be activated by phosphorylation $(17,18)$. Maroni et al mentioned that inhibition of the p38MAPK pathway resulted in the inhibition of DNA synthesis, cell growth and proliferation of PC-3 cells (16). Therefore, putative changes in the activity of p38MAPK caused by alterations of the possible interaction with C13orf19 are of interest.

Three experiments have been performed to analyze the putative interaction between C13orf19 and p38MAPK: i) the siRNA-mediated inhibition of C13orf19 mRNA expression did not change the proportion of phosphorylated to total p38MAPK; ii) treatment with the p38MAPK inhibitor, SB203580, did not alter the C13orf19 mRNA expression; and iii) to identify novel interaction partners of C13orf19, a yeast two-hybrid matrix screen (8) was performed. This screen had the potential to detect the physical interaction between C13orf19 and the two isoforms p38 $\alpha$ and p38 of p38MAPK but did not reveal any interaction partners. Neither of the three experiments positively verified the postulated interaction of C13orf19 and p38MAPK. Therefore, the designation of the gene as P38IP is misleading and it should forthwith be referred to as C13orf19 or FAM48A. The data shown here and in previous studies describe C13orf19 as differentially 
expressed in $\mathrm{PCa}$ but do not suggest any association with growth properties of $\mathrm{BPH}$ and $\mathrm{PCa}$ cells.

\section{Acknowledgements}

The authors wish to thank Dr M. Kotzsch (Institute for Pathology, Technical University Dresden) for his help with the cytofluorometric analyses. We further thank Dr Ulrich Stelzl and Professor Erich Wanker (Max Delbück Centrum, Berlin-Buch, Germany) for performing Y2H matrix screens. We also thank Kai Kraemer for helpful discussion. This study was partially supported by a grant from the WilhelmSander-Stiftung (to A.M. and M.P.W.).

\section{References}

1. Jemal A, Murray T, Ward E, Samuels A, Tiwari RC, Ghafoor A, Feuer EJ and Thun MJ: Cancer statistics 2005. CA Cancer J Clin 55: 10-30, 2005.

2. Visakorpi T, Kallioniemi AH, Syvanen AC, Hyytinen ER, Karhu R, Tammela T, Isola JJ and Kallioniemi OP: Genetic changes in primary and recurrent prostate cancer by comparative genomic hybridization. Cancer Res 55: 342-347, 1995.

3. Von Knobloch R, Konrad L, Barth PJ, Brandt H, Wille S, Heidenreich A, Moll R and Hofmann R: Genetic pathways and new progression markers for prostate cancer suggested by microsatellite allelotyping. Clin Cancer Res 10: 1064-1073, 2004.

4. Schmidt U, Fiedler U, Pilarsky CP, Ehlers W, Fuessel S, Haase M, Faller G, Sauter G and Wirth MP: Identification of a novel gene on chromosome 13 between BRCA-2 and RB-1. Prostate 47: 91-101, 2001.

5. Fiedler U, Ehlers W, Meye A, Fuessel S, Schmidt U and Wirth MP: LOH analyses in the region of the putative tumor suppressor gene C13 on chromosome 13q13. Anticancer Res 27: 2341-2350, 2001.

6. Schmidt U, Fuessel S, Haase M, Kraemer K, Meye A and Wirth MP: Quantification of C13orf19/P38IP mRNA expression by quantitative real-time PCR in patients with urological malignancies. Cancer Lett 225: 253-260, 2005.

7. Lipshutz RJ, Fodor SPA, Gingeras TR and Lockhart DJ: High density synthetic oligonucleotide arrays. Nat Genet 21: 20-24, 1999.
8. Stelzl U, Worm U, Lalowski M, Haenig C, Brembeck FH, Goehler H, Stroedicke M, Zenkner M, Schoenherr A, Koeppen S, Timm J, Mintzlaff S, Abraham C, Bock N, Kietzmann S, Goedde A, Toksoz E, Droege A, Krobitsch S, Korn B, Birchmeier W, Lehrach $\mathrm{H}$ and Wanker EE: A human proteinprotein interaction network: a resource for annotating the proteome. Cell 122: 957-968, 2005.

9. Welsh JB, Sapinoso LM, Su AI, Kern SG, Wang-Rodriguez J, Moskaluk CA, Frierson HF Jr and Hampton GM: Analysis of gene expression identifies candidate markers and pharmacological targets in prostate cancer. Cancer Res 61: 5974-5978, 2001.

10. Singh D, Febbo PG, Ross K, Jackson DG, Manola J, Ladd C, Tamayo P, Renshaw AA, D'Amico AV, Richie JP, Lander ES, Loda M, Kantoff PW, Golub TR and Sellers WR: Gene expression correlates of clinical prostate cancer behavior. Cancer Cell 1: 203-209, 2002.

11. Ramaswamy S, Tamayo P, Rifkin R, Mukherjee S, Yeang CH, Angelo M, Ladd C, Reich M, Latulippe E, Mesirov JP, Poggio T, Gerald W, Loda M, Lander ES and Golub TR: Multiclass cancer diagnosis using tumor gene expression signatures. Proc Natl Acad Sci USA 98: 15149-15154, 2001.

12. Luo J, Duggan DJ, Chen Y, Sauvageot J, Ewing CM, Bittner ML, Trent JM and Isaacs WB: Human prostate cancer and benign prostatic hyperplasia: molecular dissection by gene expression profiling. Cancer Res 61: 4683-4688, 2001.

13. Luo JH, Yu YP, Cieply K, Lin F, Deflavia P, Dhir R, Finkelstein S, Michalopoulos G and Becich M: Gene expression analysis of prostate cancers. Mol Carcinog 33: 25-35, 2002.

14. Dhanasekaran SM, Barrette TR, Ghosh D, Shah R, Varambally S, Kurachi K, Pienta KJ, Rubin MA and Chinnaiyan AM: Delineation of prognostic biomarkers in prostate cancer. Nature 412: 822-826, 2001 .

15. LaTulippe E, Satagopan J, Smith A, Scher H, Scardino P, Reuter V and Gerald WL: Comprehensive gene expression analysis of prostate cancer reveals distinct transcriptional programs associated with metastatic disease. Cancer Res 62: 4499-4506, 2002.

16. Maroni PD, Koul S, Meacham RB and Koul HK: Mitogen activated protein kinase signal transduction pathways in the prostate. Cell Commun Signal 2: 5-17, 2004.

17. Royuela M, Arenas MI, Bethencourt FR, Sanchez-Chapado M, Fraile B and Paniagua R: Regulation of proliferation/apoptosis equilibrium by mitogen-activated protein kinases in normal, hyperplastic, and carcinomatous human prostate. Hum Pathol 33: 299-306, 2002.

18. Uzgare AR, Kaplan PJ and Greenberg NM: Differential expression and/or activation of P38MAPK, erk1/2, and jnk during the initiation and progression of prostate cancer. Prostate 55: 128-139, 2003. 